Journal of Plant Production

Journal homepage: www.jpp.mans.edu.eg

Available online at: www.jpp.journals.ekb.eg

\title{
Effect of Foliar Spraying with Compounds Rich in Potassium and Phosphorus as an Alternative to Soil Addition on the Growth, Productivity and Quality of Cotton
}

\author{
EL-Shazly, M. W. M. ${ }^{*}$ and A. M. Abd El All ${ }^{2}$
}

Cross Mark

${ }^{1}$ Cotton Physiology Department, Cotton Research Institute, Agricultural Research Center, Giza, Egypt.

${ }^{2}$ Agricultural Botany Department, Faculty of Agriculture, Shebin El-Kom, Menoufia University.

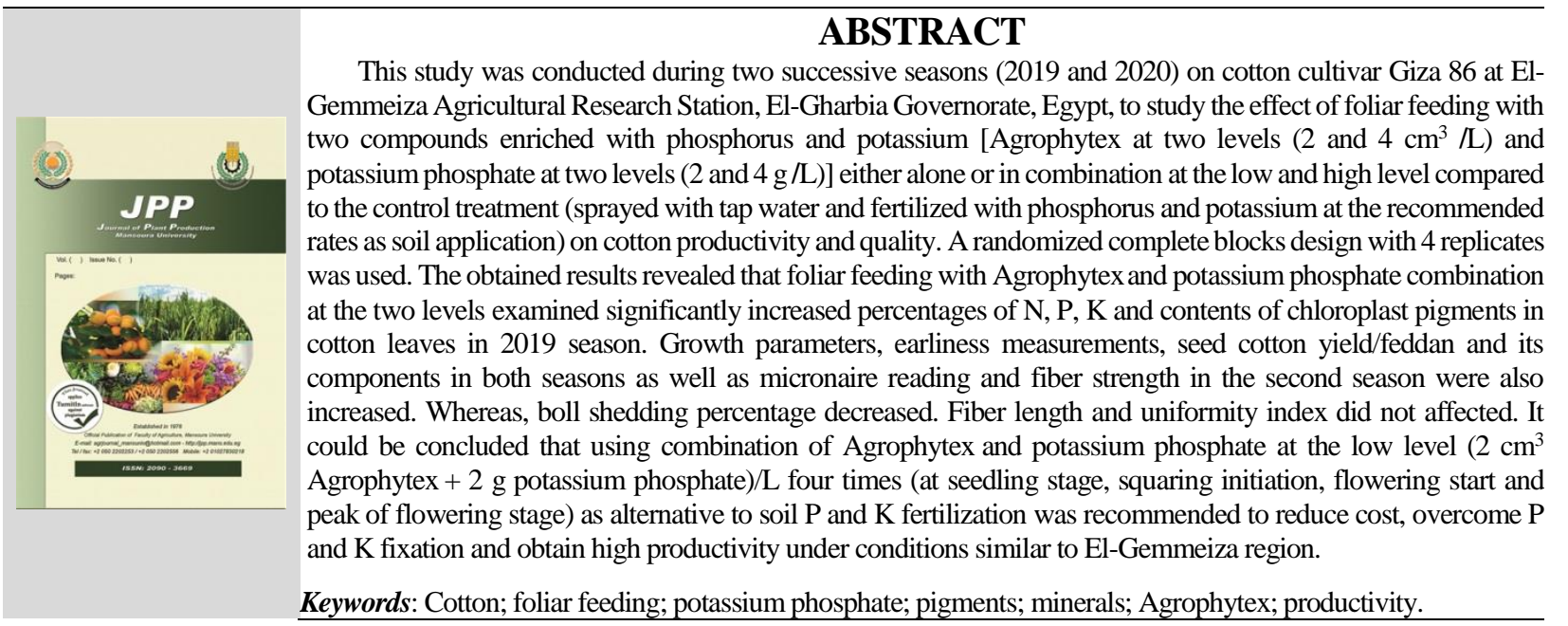

\section{INTRODUCTION}

In arid environments, cotton nutrition is a key component of high productivity, where applied NPK fertilizer as foliar spraying was helpful in producing the highest seed cotton yield ha ${ }^{-1}$, bolls number plant ${ }^{-1}$ and boll weight (Karim et al., 2016). Cotton plant needs macro and micro-nutrients in balanced ratios with none deficient and none in excess for optimum and economical yield. Applied soil fertilizers especially $\mathrm{P}$ and $\mathrm{K}$ fertilizers are very important for plant growth and development as well as several essential biochemical and physiological processes in cotton as reported by Uchida (2000), Lynch (2011), Wang et al. (2012), Oosterhuis et al. (2013), Fahad et al. (2016) and Ali et al. (2018). Moreover, it was found that potassium plays a vital role in cotton fiber development and a shortage will result in lowered fiber quality and yield reduction. It's involved in providing the turgor pressure necessary for fiber elongation, where it is a major solute in the fiber (single cells), Oosterhuis and Bednarz (1997) and Hu et al. (2018). During active fiber growth if $\mathrm{K}$ supply is inadequate, there will be a reduction in turgor pressure of the fiber resulting in less cell elongation and shorter fibers at maturity. As $\mathrm{K}$ is associated with the sugars transport, it is likely implicated with deposition of fibers secondary wall and therefore, related to fiber micronaire and strength.

However, some challenges face soil phosphorus and potassium availability for plants, where soil potassium and phosphorus fertilizers are rendered unavailable to cotton plants (Oosterhuis, 2001). Inadequate $\mathrm{P}$ and $\mathrm{K}$ affected negatively on cotton yield and its quality. A higher need for $\mathrm{K}$ by earlier maturing, higher-yielding, faster-fruiting cultivars coupled with the decline in root growth during boll filling was detected (Oosterhuis et al., 1991).

Hence alternate methods of soil $\mathrm{K}$ and $\mathrm{P}$ fertilizer application might be useful. In this context, it was found that foliar feeding with potassium and phosphorus fertilizers seems a proper option to supply cotton plants with their $\mathrm{K}$ and $\mathrm{P}$ requirements (Hussain et al., 2020). Foliar fertilization is one of the modern methods of high economic efficiency. It has certain potential benefits as reported by Sharpley et al. (2018). They found that use of small amounts of potassium and phosphate of fertilizer as a foliar application is appropriate compared to soil fertilization and low cost. Foliar fertilization can overcome the problems of soil factors that lead to the low rate of manure utilization and loss of fertilizer or fixing. The plant's rapid supply for elements needs when root absorption of nutrients has often ceased during flowering or the beginning of the development of seeds and fruits (Oosterhuis et al., 1990). Ground fertilization is limited to roots only and needs time to reach the other organs.. While, the use of foliar spray quickly compensates for the shortage of these elements and can get all parts of the plant for ease (El-Fouly and ElSayed, 1997). In foliar application, the nutrient elements are easily absorbed by leaves and avoid the use of excessive concentration of $\mathrm{K}$ which can cause leaf damage and avoid the use of the higher rates of $\mathrm{P}$ which accumulates at the soil 
surface due to soil erodes and/or surface water flows over Penriched soil, most of the $\mathrm{P}$ in liquid $\mathrm{P}$ fertilizers precipitates as calcium/magnesium phosphates in alkaline soils and $\mathrm{P}$ is not very mobile in soil (Amberger, 1993).

On the other hand, Abdel-Gayed et al. (2020) using monoammonium phosphate (MAP) as $1 \%$ foliar spraying twice and they found that phosphorus was significantly increased growth parameters, seed cotton yield and seed index, while lint\% decreased. Similarly, earliness percentage was positively responded to phosphorus. Whereas, fiber properties were not affected. Ahmad et al. (2020) found that phosphorous application significantly enhanced quality and seed cotton yield in terms of bolls number plant ${ }^{-1}$, boll weight, lint yield and ginning out turn. Ali et al. (2020) reported that phosphorus deficiency causes the reduction of plant growth, flowering, imbalanced pollination, boll size and inhibits dark green leaves and flower bud necrosis. Aslam et al. (2020) recommended dose of NPK $+2 \% \mathrm{~K}_{2} \mathrm{O}$ foliar spray twice at both 80 and 105 days of sowing that effects on seed cotton yield as well as boll weight. Hussain et al. (2020) found that foliar application with $\mathrm{K}_{2} \mathrm{SO}_{4}$ produced the highest cotton productivity and profitability. However, total boll weight per plant was similar in foliar applied $\mathrm{K}_{2} \mathrm{SO}_{4}$ and $\mathrm{KNO}_{3}$ basal application. Better boll opening in foliar applied $\mathrm{K}_{2} \mathrm{SO}_{4}$ perhaps, played decisive role for increased seed-cotton yield.

The present study aimed to investigate the importance of using leaf fertilization as successful alternate technique of soil fertilization on Egyptian cotton cv. Giza 86 productivity and fiber quality as well as the ability of cotton to absorb nutrients were evaluated. Two compounds enriched with phosphorus and potassium at two levels were examined either alone or in combination compared to the control treatment under El-Gemmeiza region.

\section{MATERIALS AND METHODS}

This research was conducted during 2019 and 2020 seasons on cotton cultivar Giza 86 (Gossypium barbadense L.) at El-Gemmeiza Agricultural Research Station, ElGharbia Governorate, Egypt.

Prior to planting, representative soil samples were taken from different parts of the field $(0-30 \mathrm{~cm})$ depth, mixed and analysed according to Chapman and Parker (1981). The results of soil analysis are depicted in Table 1.

Two compounds enriched with phosphorus and potassium [Agrophytex ${ }^{\circledR}\left(40 \% \mathrm{P}_{2} \mathrm{O}_{5}+30 \% \mathrm{~K}_{2} \mathrm{O}\right)$ and potassium phosphate $\left.\left(52 \% \quad \mathrm{P}_{2} \mathrm{O}_{5}+34 \% \quad \mathrm{~K}_{2} \mathrm{O}\right)\right]$ were examined. Two levels from each were sprayed either alone or in combination compared to the control. Control treatment was fertilized in both seasons as soil addition by ordinary super phosphate $\left(15.5 \% \mathrm{P}_{2} \mathrm{O}_{5}\right)$ at the rate of $22.5 \mathrm{~kg} \mathrm{P}_{2} \mathrm{O}_{5} /$ fed before sowing and potassium sulphate $\left(48 \% \mathrm{~K}_{2} \mathrm{O}\right)$ at the rate of ( $24 \mathrm{~kg} \mathrm{~K} 2 \mathrm{O} / \mathrm{fed})$ was side-dressed in a single dose after thinning before irrigation. In both seasons, all treatments were fertilized with nitrogen fertilizer in the form of urea $(46 \% \mathrm{~N})$ at the rate of $45 \mathrm{~kg} \mathrm{~N} / \mathrm{fed}$ side-dressed in two equal splits after thinning before irrigation and 15 days later before the following irrigation. Other cotton cultural and agronomic practices were adopted from sowing to harvest as recommended by Cotton Research Institute (CRI), Agricultural Research Center (ARC), Egypt.
Table 1. Mechanical and chemical properties of soil sites in 2019 and 2020 seasons

\begin{tabular}{|c|c|c|c|}
\hline Properties & & $\begin{array}{c}2019 \\
\text { season }\end{array}$ & $\begin{array}{c}2020 \\
\text { season }\end{array}$ \\
\hline \multicolumn{4}{|c|}{ Mechanical analysis: } \\
\hline Clay & & 44.2 & 45.1 \\
\hline Silt & & 33.0 & 32.6 \\
\hline Sand & $\%$ & 22.8 & 22.3 \\
\hline Texture & & clayey & clayey \\
\hline \multicolumn{4}{|c|}{ Chemical analysis: } \\
\hline $\mathrm{pH}$ & & 8.1 & 7.9 \\
\hline $\mathrm{EC}$ & $\mathrm{ds} / \mathrm{m}^{2}$ & 0.99 & 0.64 \\
\hline Organic matter & $\%$ & 1.40 & 1.25 \\
\hline Total N & & 49.00 & 43.75 \\
\hline Available P & & 1.28 & 0.96 \\
\hline Available K & $(\mathrm{mo} / 100 \mathrm{r})$ & 31.0 & 21.0 \\
\hline Available Mg & (mg/l00g) & 23 & 20 \\
\hline Available Fe & & 12.4 & 10.7 \\
\hline Available Mn & & 3.9 & 3.1 \\
\hline Available Zn & & 1.12 & 1.20 \\
\hline Available $\mathrm{Cu}$ & (ppm) & 1.7 & 0.9 \\
\hline
\end{tabular}

The previous crop was Egyptian clover "berseem" in both seasons

The experiment was set up in a randomized complete blocks design with 4 replicates in both seasons, where the following seven treatments were applied:

$\mathrm{T}_{1}$-Control (sprayed with the same amount of tap water at the application times of foliar feeding with the two tested compounds and fertilized with phosphorus and potassium at the recommended rates as soil application) $\mathrm{T}_{2}$ - Foliar feeding with Agrophytex at the level of $2 \mathrm{~cm}^{3} / \mathrm{L}$ $\mathrm{T}_{3}$ - Foliar feeding with Agrophytex at the level of $4 \mathrm{~cm}^{3} / \mathrm{L}$

$\mathrm{T}_{4}$-Foliar feeding with potassium phosphate at the level of $2 \mathrm{~g} / \mathrm{L}$

$\mathrm{T}_{5}$-Foliar feeding with potassium phosphate at the level of $4 \mathrm{~g} / \mathrm{L}$

$\mathrm{T}_{6}$ - Foliar feeding with Agrophytex and potassium phosphate at the low level $\left(2 \mathrm{~cm}^{3}\right.$ and $\left.2 \mathrm{~g}\right) / \mathrm{L}$

$\mathrm{T}_{7}$ - Foliar feeding with Agrophytex and potassium phosphate at the high level $\left(4 \mathrm{~cm}^{3}\right.$ and $\left.4 \mathrm{~g}\right) / \mathrm{L}$

In both seasons, the experimental plot size was $14 \mathrm{~m}^{2}$ included 5 ridges ( $4 \mathrm{~m}$ long and $70 \mathrm{~cm}$ wide) with hills $25 \mathrm{~cm}$ apart leaving 2 vigour seedlings/hill at thinning time to insure 48,000 plants/fed.

Seed sowing and spraying plant leaves were taking place as shown in Table 2. Dates of foliar feeding coincide with the planting physiology stages; seedling stage, squaring initiation, flowering start and peak of flowering stage.

Table 2. Date of sowing and spraying with Agrophytex ${ }^{\circledR}$ and potassium phosphate in the two growing seasons, 2019 and 2020.

\begin{tabular}{ccccc}
\hline \multirow{2}{*}{$\begin{array}{c}\text { Sowing } \\
\text { date }\end{array}$} & $\begin{array}{c}\text { Seedling } \\
\text { stage }\end{array}$ & $\begin{array}{c}\text { Squaring } \\
\text { initiation }\end{array}$ & $\begin{array}{c}\text { Flowering } \\
\text { start }\end{array}$ & $\begin{array}{c}\text { Peak of } \\
\text { flowering stage }\end{array}$ \\
\hline $10 / 4 / 2019$ & $16 / 5$ & $27 / 5$ & $2 / 7$ & $20 / 7$ \\
$14 / 4 / 2020$ & $20 / 5$ & $1 / 6$ & $6 / 7$ & $24 / 7$ \\
\hline
\end{tabular}

Spraying was done by using hand operated sprayer compressed air at the rate of 200 liter water/fed. Cotton leaves were sprayed on both sides to run-off using Tween 20 $(0.01 \%)$ as a non-ionic surfactant.

\section{Studied characters:}

A- Leaves chemical composition: In 2019 season, after 115 days from sowing (after 15 days from the last spraying of the two compounds enriched with phosphorus and potassium under study), a leaf sample of 20 leaves (blade + petiole) was 
taken at random from the youngest fully matured leaves $\left(4^{\text {th }}\right.$ leaf from the apex of the main stem) from plants of each plot to determine the percentages of $\mathrm{N}, \mathrm{P}$ and $\mathrm{K}$ according to Chapman and Parker (1981). Chlorophyll (a), (b) and total chlorophyll (mg/g dry weight) were determined as reported by Fadeel (1962). Carotenoids concentration (mg/g dry weight) was also determined in cotton leaves as described in A.O.A.C. (1995).

B-Growth parameters: In both seasons, six guarded plants were taken at random from each plot carefully after 115 days from sowing to determine dry weight of assimilatory parts (above ground)/plant, where above ground parts were washed and dried to a constant weight in a forced air oven at $70{ }^{\circ} \mathrm{C}$ then, dry weight was calculated. Leaf area index (LAI) was determined as proposed by Hunt (1978). At harvesting, ten representative plants from each plot were taken at random to determine final plant height $(\mathrm{cm})$ and its number of fruiting branches.

C-Earliness measurements: Ten representative plants of each plot were taken at random. The following earliness measurements were calculated according to Richmond and Radwan (1962) and Kadapa (1975); 1- Number of total flowers per plant, 2- Number of total bolls set per plant, 3Boll setting percentage, 4- Boll shedding percentage and 5Earliness\% (percentage of the first picking yield to total yield).

D- Seed cotton yield and its contributory characters: At harvesting, data were taken from the above ten representative plants to determine the following yield contributory characters; 1- Number of open bolls per plant, 2- Boll weight (g), 3- Lint percentage as percentage of lint cotton to seed cotton after ginning and 4-Seed index. The seed cotton yield per feddan was estimated as the weight of seed cotton in kilograms picked twice from each plot and transformed to kentars per feddan (one kentar $=157.5 \mathrm{~kg}$ )

E- Fiber traits; $2.5 \%$ span length (mm) and uniformity ratio (\%) were determined by a digital fibrograph instrument, micronaire reading (a combined measure of fiber fineness and fiber maturity) was measured by a micronaire instrument and fiber strength (Pressley units) was measured by the Pressley instrument according to A.S.T.M. (2012) at the C.R.I. laboratories, Giza, Egypt.

The statistical analysis of the data in the two seasons was done and performed according to Snedecor and Cochran (1980). The treatments means were compared using LSD at 0.05 level of probability.

\section{RESULTS AND DISCUSSION}

\section{A-Leaves chemical composition:}

\section{A.1. N, P and K:}

Results in Table 3 indicated that foliar feeding with Agrophytex and potassium phosphate at the two levels examined either alone or in combination significantly increased nitrogen, phosphorus and potassium percentages in cotton leaves with a favour of the latter compared to the control. The highest N, P and K percentages (4.50, 0.58 and $3.65 \% ; 4.40,0.57$ and $3.63 \%$ ) were obtained from foliar feeding with Agrophytex and potassium phosphate at the high level $\left(4 \mathrm{~cm}^{3}\right.$ Agrophytex $+4 \mathrm{~g}$ potassium phosphate)/L, followed by foliar feeding with Agrophytex and potassium phosphate at the low level $\left(2 \mathrm{~cm}^{3}\right.$ Agrophytex +2 g potassium phosphate)/L, respectively. The lowest percentages of nitrogen, phosphorus and potassium (3.20, 0.41 and 3.30\%) were obtained from the control (fertilized with phosphorus and potassium at the recommended rates as soil application and sprayed with tap water at the application times).

Table 3. Effect of foliar application with Agrophytex and/or potassium phosphate at two levels on cotton leaves chemical composition in 2019 season.

\begin{tabular}{|c|c|c|c|c|c|c|c|}
\hline \multirow{3}{*}{ Treatments } & \multirow[t]{2}{*}{$\mathbf{N}$} & \multirow[t]{2}{*}{$\mathbf{P}$} & \multirow[t]{2}{*}{$\mathbf{K}$} & \multicolumn{3}{|c|}{ Chlorophyll } & \multirow{2}{*}{ carotenoids } \\
\hline & & & & $\mathbf{a}$ & b & $(\mathbf{a}+\mathbf{b})$ & \\
\hline & \multicolumn{3}{|c|}{$(\%)$} & \multicolumn{4}{|c|}{ (mg /g dry weight) } \\
\hline T & 3.20 & 0.41 & 3.30 & 3.84 & 1.19 & 5.03 & 1.24 \\
\hline $\mathrm{T}_{2}$-Agrophytex, $2 \mathrm{~cm}^{3} / \mathrm{L}$. & 3.44 & 0.48 & 3.51 & 4.18 & 1.27 & 5.45 & 1.29 \\
\hline $\mathrm{T}_{3}$-Agrophytex, $4 \mathrm{~cm}^{3} / \mathrm{L}$. & 3.70 & 0.51 & 3.52 & 4.27 & 1.32 & 5.59 & 1.44 \\
\hline $\mathrm{T}_{4}$-Potassium phosphate, $2 \mathrm{~g} / \mathrm{L}$. & 3.90 & 0.52 & 3.57 & 4.13 & 1.41 & 5.54 & 1.49 \\
\hline $\mathrm{T}_{5}$-Potassium phosphate, $4 \mathrm{~g} / \mathrm{L}$. & 4.10 & 0.54 & 3.61 & 4.44 & 1.53 & 5.97 & 1.57 \\
\hline $\mathrm{T}_{6^{-}}\left(\mathrm{T}_{2}+\mathrm{T}_{4}\right)$ & 4.40 & 0.57 & 3.63 & 4.81 & 1.95 & 6.76 & 1.97 \\
\hline $\mathrm{T}_{7-}\left(\mathrm{T}_{3}+\mathrm{T}_{5}\right)$ & 4.50 & 0.58 & 3.65 & 4.82 & 1.96 & 6.78 & 1.99 \\
\hline LSD at 0.05 & 0.17 & 0.02 & 0.06 & 0.01 & 0.02 & 0.02 & 0.03 \\
\hline
\end{tabular}

These results may be due to the presence of $\mathrm{P}$ and $\mathrm{K}$ at a high level in the two sources examined and the experimental claying soil being low in organic matter, High $\mathrm{pH}$ and moderate in total $\mathrm{N}$ (Table 1) and the supplied of the high $\mathrm{PK}$ as foliar spraying increased leaf $\mathrm{N}$ content. Agrophytex contains $\left(40 \% \mathrm{P}_{2} \mathrm{O}_{5}+30 \% \mathrm{~K}_{2} \mathrm{O}\right)$ and potassium phosphate contains $\left(52 \% \mathrm{P}_{2} \mathrm{O}_{5}+34 \% \mathrm{~K}_{2} \mathrm{O}\right)$. Thus, they reflected in significant increase in these nutrients' uptake by plants (Table 3). Dev et al. (2007) found that the K application significantly increased the $\mathrm{N}$ uptake of the plant. Leaf phosphorus content increased with increasing $\mathrm{P}$ availability and increased uptake to added $\mathrm{P}$. The experimental soil sites are clayey with high $\mathrm{pH}$. In addition, these conditions contributed to more $\mathrm{P}$ and $\mathrm{K}$ fixation by clay minerals and reduction of their availability (Mengel and Kirkby, 1987). It was found that $\mathrm{P}$ significantly enhanced $\mathrm{N}$ and $\mathrm{K}$ uptake
(Sawan et al., 2008) compared to the control by increasing the pool of ATP (Read et al., 2006).

In this respect, Mengel and Kirkby (1987) recorded that $\mathrm{K}^{+}$ion competes with nitrogen for selective binding sites in the adsorption process. More $\mathrm{P}$ fixation occurs in soil with higher $\mathrm{pH}$ and the need of $\mathrm{P}$ for medium fertile soil was higher (Malik et al., 1992). Deshpande and Lakhdive (1994) found that $\mathrm{P}$ application increased uptake and content of $\mathrm{P}$ in leaf. El-Shazly et al. (2003) found that two foliar sprays of $\mathrm{K}_{2} \mathrm{O}$ as $\mathrm{K}_{2} \mathrm{SO}_{4}$ at two levels i.e., $0.2 \%$ and $0.4 \%$ at each spray gave the highest $\mathrm{N}, \mathrm{P}$ and $\mathrm{K}$ percentages in cotton leaves compared to the control treatment.

\section{A.2. Photosynthetic pigments:}

Foliar feeding with the examined two compounds' rich with phosphorus and potassium affected significantly cotton leaves concentration of the photosynthetic pigments 
(chlorophyll a, b and a+b) as shown in Table 3. Leaves of plants treated with the combination between the two compounds either at the low level $\left(2 \mathrm{~cm}^{3}\right.$ Agrophytex $+2 \mathrm{~g}$ potassium phosphate)/L or at the high level $\left(4 \mathrm{~cm}^{3}\right.$ Agrophytex $+4 \mathrm{~g}$ potassium phosphate)/L showed greater contents of the photosynthetic pigments (chlorophyll a, b and $\mathrm{a}+\mathrm{b}$ ) in cotton leaves compared to untreated control. Leaves carotenoids concentration also showed a similar response to these two combinations (Table 3 ).

The positive effect of these two combinations either at the high or low levels may be due to; The significant increase of leaves $\mathrm{N}, \mathrm{P}$ and $\mathrm{K}$ percentages due to these two combinations, where sufficient $\mathrm{K}$ can prolong the period of leaf active photosynthesis and improved synthesis of chlorophyll through its role as a structural and catalytic component of proteins, enzymes, and as co-factor for normal development of pigment biosynthesis. Nitrogen involved directly in photosynthesis, where it is the important constituent of chlorophyll (Rajasekar et al., 2017). Conversion of $\mathrm{CO}_{2}$ to sugar depends on the role of phosphoglycric acid and phosphoglecric compounds, where $\mathrm{P}$ is a necessary component of these compounds and it is required to produce pyridoxal for the biosynthesis of chlorophyll (Uchida, 2000).

In this regard, Sawan et al. (2008) reported that NPK making the tissue become green through stimulator chlorophyll biosynthesis. The protecting role of carotenoids on chlorophyll against light oxidation and scavenging singlet oxygen and other toxic oxygen species formed within the chloroplast was detected by Young (1991). He reported that carotenoid protects cell enzymes against harmful effect of blue and violet rays (light rays of short waves) by absorbing these rays. Moreover, carotenoid acts as energy transferring and accessory light-harvesting pigments.

\section{B-Growth parameters:}

Data in Table 4 indicated that leaf area index and total dry weight of assimilatory parts/plant after 115 days from sowing, final plant height and its number of fruiting branches at harvesting were significantly affected by foliar feeding with the two compounds examined in both seasons of the study with a favour of the combination between the two compounds at the high level $\left(4 \mathrm{~cm}^{3}\right.$ Agrophytex $+4 \mathrm{~g}$ potassium phosphate)/L, followed by the low level $\left(2 \mathrm{~cm}^{3}\right.$ Agrophytex + $2 \mathrm{~g}$ potassium phosphate)/L compared to the control which produced the lowest values of these traits. The respective values due to these treatments in the first season were 3.74 , $129.20 \mathrm{~g}, 164.25 \mathrm{~cm}$ and $16.90 \mathrm{branch} ; 3.60,128.67 \mathrm{~g}, 164.08$ $\mathrm{cm}$ and 16.78 branch and $2.59,96.07 \mathrm{~g}, 154.18 \mathrm{~cm}$ and 14.55 branch and in the second season were $3.31,128.00 \mathrm{~g}, 163.00$ $\mathrm{cm}$ and16.83 branch; $3.29,125.80 \mathrm{~g}, 162.58 \mathrm{~cm}$ and 16.08 branch and $2.74,90.00 \mathrm{~g}, 154.03 \mathrm{~cm}$ and 14.05 branch. These growth parameters in concern significantly increased due to all foliar feeding treatments compared with the control plants. Moreover, the high level of potassium phosphate achieved high leaf area index and total dry weight of assimilatory parts/plant after 115 days old as compared to the low level of the same compound or the low or high levels of the other compound (Agrophytex). However, the high level of Agrophytex achieved high plant height at harvesting and its number of fruiting branches as compared to the low level of the same compound or the low or high levels of the other compound (potassium phosphate).

Table 4. Effect of foliar application with Agrophytex and/or potassium phosphate at two levels on cotton growth parameters in 2019 and 2020 seasons

\begin{tabular}{|c|c|c|c|c|}
\hline \multirow[t]{2}{*}{ Treatments } & $\begin{array}{c}\text { Leaf area } \\
\text { index }\end{array}$ & $\begin{array}{c}\text { dry weight of } \\
\text { assimilatory parts } \\
\left.\text { (g plant }^{-1}\right)\end{array}$ & $\begin{array}{c}\text { Number of } \\
\text { fruiting branches } \\
\text { Plant }^{-1}\end{array}$ & $\begin{array}{c}\text { Final plant } \\
\text { height } \\
(\mathrm{cm})\end{array}$ \\
\hline & \multicolumn{4}{|c|}{2019 season } \\
\hline $\mathrm{T}_{1}$-Control. & 2.59 & 96.07 & 14.55 & 154.18 \\
\hline $\mathrm{T}_{2}$-Agrophytex, $2 \mathrm{~cm}^{3} / \mathrm{L}$. & 2.78 & 111.07 & 16.05 & 159.28 \\
\hline $\mathrm{T}_{3}$-Agrophytex, $4 \mathrm{~cm}^{3} / \mathrm{L}$ & 2.98 & 115.83 & 16.48 & 160.43 \\
\hline $\mathrm{T}_{4}$-Potassium phosphate, $2 \mathrm{~g} / \mathrm{L}$. & 3.14 & 119.83 & 15.58 & 157.95 \\
\hline $\mathrm{T}_{5}$-Potassium phosphate, $4 \mathrm{~g} / \mathrm{L}$. & 3.28 & 123.13 & 15.88 & 158.05 \\
\hline $\mathrm{T}_{6^{-}}\left(\mathrm{T}_{2}+\mathrm{T}_{4}\right)$ & 3.60 & 128.67 & 16.78 & 164.08 \\
\hline $\mathrm{T}_{7}-\left(\mathrm{T}_{3}+\mathrm{T}_{5}\right)$ & 3.74 & 129.20 & 16.90 & 164.25 \\
\hline LSD at 0.05 & 0.06 & 1.44 & 0.33 & 0.60 \\
\hline Treatments & \multicolumn{4}{|c|}{2020 season } \\
\hline $\mathrm{T}_{1}-$ Control. & 2.74 & 90.00 & 14.05 & 154.03 \\
\hline $\mathrm{T}_{2}$-Agrophytex, $2 \mathrm{~cm}^{3} / \mathrm{L}$. & 2.87 & 101.60 & 15.85 & 157.45 \\
\hline $\mathrm{T}_{3}$-Agrophytex, $4 \mathrm{~cm}^{3} / \mathrm{L}$ & 2.89 & 105.40 & 16.15 & 158.95 \\
\hline $\mathrm{T}_{4}$-Potassium phosphate, $2 \mathrm{~g} / \mathrm{L}$. & 2.92 & 106.20 & 15.08 & 155.83 \\
\hline $\mathrm{T}_{5}$-Potassium phosphate, $4 \mathrm{~g} / \mathrm{L}$. & 3.05 & 112.40 & 15.50 & 157.98 \\
\hline $\mathrm{T}_{6}-\left(\mathrm{T}_{2}+\mathrm{T}_{4}\right)$ & 3.29 & 125.80 & 16.08 & 162.58 \\
\hline $\mathrm{T}_{7^{-}}\left(\mathrm{T}_{3}+\mathrm{T}_{5}\right)$ & 3.31 & 128.00 & 16.83 & 163.00 \\
\hline LSD at 0.05 & 0.03 & 1.28 & 0.49 & 1.11 \\
\hline
\end{tabular}

The significant increase in growth parameters due to the application of the two compounds could be attributed to: The significant increase in photosynthetic pigments reflects in significant increase in production of assimilates by the source (sufficient leaves area) and consequently significant increase in assimilatory parts dry weight (g/plant) may be detected (Table 4). The levels of $K$ and $P$ nutrition affected the leaves efficiency in the transformation of solar energy into ATP for photosynthate assimilation (Hartt, 1972). The significant increase in percentages of $\mathrm{K}, \mathrm{N}$ and $\mathrm{P}$ in cotton leaves were also included (Table 3 ), where potassium increases both the quantity and the distance that photosynthate moved from the source (leaves) to sink (fruiting organs). Potassium regulates many vital functions like carbon assimilation, translocation of proteins and sugars, water balance in plants, maintaining turgor pressure in the seed and root development. Nitrogen 
gives favourable impact on active growth of green meristematic regions. It plays an important role in synthesis, distributing and accumulating the important substances responsible for growth and reflected greatly on total dry weight of plant assimilatory parts (Hearn, 1981). Phosphorus is important in promoting early rooting. It is involved in plant energy storage and transfer (Bronson and Boman, 2009). P is also involved in cell division and development of meristematic tissues (Gilbert, 2009). Phosphorus deficiency leads to a reduction in the rate of leaf expansion and photosynthesis per unit leaf area (Mai et al., 2018). The high soil $\mathrm{pH}(8.1$ and 7.9) noticed in Table 1 results in precipitation of $\mathrm{P}$, which reduces the soluble $\mathrm{P}$ supply. When plants are deprived of phosphorus at early stages $\mathrm{P}$ deficiency tends to limit the growth (Parfitt et al., 2008). The high level is considered as a proper level for good growth and thereby pushed cotton plants to have a profitable growth expressed as greater leaf area/plant and higher $\mathrm{N}$ percentage in leaves which is essential for protoplasm and protein building up and cell division which resulted in an increase in cell number and size with an overall increase in leaf area (Table 4). Higher P supply increased cell expansion by increasing hydraulic conductance inside plants, which may lead to increased plant size and leaf area expansion. Phosphate deficiency induced early leaf senescence (Radin and Eidenbock, 1984).

Application of compounds enriched in $\mathrm{P}$ and $\mathrm{K}$ might increase percentages of nitrogen, phosphorus and potassium in leaf and other parts (Table 3) which increase availability of the nutrients to the plants, establishing a better source-sink relationship. The dry matter accumulation was higher due to better photosynthesis, which resulted in a better supply of photosynthates and assimilates to the fruit, where higher supply of $\mathrm{P}$ favoured the nutrients (nitrogen and potassium) and translocation of photosynthates toward the reproductive parts rather than vegetative organs.

In this respect, enhancing phosphorus accessibility in cotton crop will ultimately enhance the plant growth with higher LAI (Arya and Singh, 2001), more expansion of leaves, increased light interception, enhanced plant height, and enhanced the sympodial branches (Mandal and Sinha, 2004). El-Shazly et al. (2003) found that two foliar sprays of $\mathrm{K}_{2} \mathrm{O}$ as $\mathrm{K}_{2} \mathrm{SO}_{4}$ at two levels i.e., $0.2 \%$ and $0.4 \%$ at each spray significantly increased number of fruiting branches/plant in the first season compared to the control treatment.

\section{C- Earliness measurements:}

Results in Table 5 indicated significant differences of total bolls and flowers numbers plant ${ }^{-1}$, boll setting $\%$, boll shedding $\%$ and first picking $\%$ in both seasons. Total flowers and total bolls numbers plant ${ }^{-1}$, boll setting\% and first picking\% were significantly increased by using the combination between the two compounds as foliar feeding at the high level $\left(4 \mathrm{~cm}^{3}\right.$ Agrophytex $+4 \mathrm{~g}$ potassium phosphate)/L followed in ranking by using the low level (2 $\mathrm{cm}^{3}$ Agrophytex $+2 \mathrm{~g}$ potassium phosphate)/L. The lowest values were produced from untreated plants in both seasons. However, boll shedding percentage follows an opposite trend.

Table 5. Effect of foliar application with Agrophytex and/or potassium phosphate at two levels on cotton earliness measurements in 2019 and 2020 seasons

\begin{tabular}{|c|c|c|c|c|c|}
\hline Treatments & $\begin{array}{c}\text { Total bolls } \\
\text { number } \\
\text { plant }^{-1}\end{array}$ & $\begin{array}{c}\text { Total flowers } \\
\text { number } \\
\text { plant }^{-1}\end{array}$ & $\begin{array}{c}\text { Boll } \\
\text { setting } \\
\%\end{array}$ & $\begin{array}{c}\text { Boll } \\
\text { shedding } \\
\%\end{array}$ & $\underset{\%}{\text { Earliness }}$ \\
\hline & & & 2019 season & & \\
\hline $\mathrm{T}_{1}$-Control. & 17.48 & 26.00 & 67.23 & 32.77 & 55.17 \\
\hline $\mathrm{T}_{2}$-Agrophytex, $2 \mathrm{~cm}^{3} / \mathrm{L}$. & 20.85 & 29.48 & 70.73 & 29.27 & 61.33 \\
\hline $\mathrm{T}_{3}$-Agrophytex, $4 \mathrm{~cm}^{3} / \mathrm{L}$. & 22.68 & 30.03 & 75.50 & 24.50 & 63.70 \\
\hline $\mathrm{T}_{4}$-Potassium phosphate, $2 \mathrm{~g} / \mathrm{L}$. & 18.23 & 26.14 & 69.74 & 30.26 & 54.36 \\
\hline $\mathrm{T}_{5}$-Potassium phosphate, $4 \mathrm{~g} / \mathrm{L}$. & 19.10 & 26.27 & 72.71 & 27.29 & 55.09 \\
\hline $\mathrm{T}_{6^{-}}\left(\mathrm{T}_{2}+\mathrm{T}_{4}\right)$ & 24.05 & 31.12 & 77.30 & 22.70 & 66.17 \\
\hline $\mathrm{T}_{7}-\left(\mathrm{T}_{3}+\mathrm{T}_{5}\right)$ & 23.33 & 29.50 & 79.08 & 20.92 & 63.82 \\
\hline LSD at 0.05 & 0.69 & 0.83 & 0.75 & 0.75 & 1.50 \\
\hline Treatments & & & 2020 season & & \\
\hline $\mathrm{T}_{1}$-Control. & 15.56 & 23.86 & 65.21 & 34.79 & 59.59 \\
\hline $\mathrm{T}_{2}$-Agrophytex, $2 \mathrm{~cm}^{3} / \mathrm{L}$. & 16.60 & 24.53 & 67.66 & 32.34 & 63.13 \\
\hline $\mathrm{T}_{3}$-Agrophytex, $4 \mathrm{~cm}^{3} / \mathrm{L}$. & 16.35 & 24.53 & 66.69 & 33.31 & 63.38 \\
\hline $\mathrm{T}_{4}$-Potassium phosphate, $2 \mathrm{~g} / \mathrm{L}$. & 16.90 & 24.63 & 68.62 & 31.38 & 59.52 \\
\hline $\mathrm{T}_{5}$-Potassium phosphate, $4 \mathrm{~g} / \mathrm{L}$. & 17.62 & 24.28 & 72.59 & 27.41 & 60.11 \\
\hline $\mathrm{T}_{6^{-}}\left(\mathrm{T}_{2}+\mathrm{T}_{4}\right)$ & 18.91 & 24.80 & 76.25 & 23.75 & 65.46 \\
\hline $\mathrm{T}_{7-}\left(\mathrm{T}_{3}+\mathrm{T}_{5}\right)$ & 18.19 & 24.76 & 73.46 & 26.54 & 66.19 \\
\hline LSD at 0.05 & 0.40 & 0.38 & 1.91 & 1.91 & 0.76 \\
\hline
\end{tabular}

The positive effect was mainly referring to the significant increase in fruiting branches number plant $\mathrm{t}^{-1}$ (Table 4), boll setting\% and reduced boll shedding\% (Table 5). Increasing boll setting\% is mainly attributed to the significant increase in percentages of nitrogen, phosphorus and potassium in cotton leaves (Table 3), and consequently producing more numbers of fruiting branches/plant (Table 4), total flowers number/plant and total bolls number/plant (Table 5). As bolls on cotton plants treated with compounds enriched in $\mathrm{P}$ and $\mathrm{K}$ have larger photosynthetic sinks for carbohydrates and other metabolites that increased the dry matter concentration. This process increases boll formation due to higher number of squares and flowers, depending on the increased photosynthetic activity (Table 5). Phosphorus has a stimulating effect on increasing flowers and bolls number plant ${ }^{-1}$, where it is a constituent of cell nucleus and essential for cell division and meristematic tissue development (Russell, 1973). Low P availability may directly affect flower bud development (Dohary et al., 2004).

In this concern, El-Shazly et al. (2003) found that two foliar sprays of $\mathrm{K}_{2} \mathrm{O}$ as $\mathrm{K}_{2} \mathrm{SO}_{4}$ at two levels i.e., $0.2 \%$ and $0.4 \%$ at each spray significantly increased earliness $\%$ in both seasons as compared with the control treatment. Sawan et al. (2008) found that spraying plants with $\mathrm{P}_{2} \mathrm{O}_{5}$ at $1728 \mathrm{~g} \mathrm{ha}^{-1}$ 
(high concentration) significantly increased yield earliness as compared with the untreated control in both seasons. Eryuce et al. (2019) reported that maturity quality percentage improved clearly by K supply.

\section{D-Seed cotton yield and its contributory characters:}

Foliar feeding with the two compounds enriched with phosphorus and potassium at the two levels examined affected significantly yield of seed cotton and its contributory characters in both seasons (Table 6). Number of open bolls plant $^{-1}$, boll weight, lint $\%$, seed index and yield of seed cotton fed $^{-1}$ were significantly reduced under control, whereas the combination between the two compounds either at the low level $\left(2 \mathrm{~cm}^{3}\right.$ Agrophytex $+2 \mathrm{~g}$ potassium phosphate $) / \mathrm{L}$ or at the high level $\left(4 \mathrm{~cm}^{3}\right.$ Agrophytex $+4 \mathrm{~g}$ potassium phosphate)/L exhibited the maximum values of these traits in consideration, where these two combinations significantly increased seed cotton yield/fed by 24.46 and $20.52 \% ; 20.77$ and $16.91 \%$ over the control treatment in 2019 and 2020 seasons, respectively.

The combination between the two compounds at the low level $\left(2 \mathrm{~cm}^{3}\right.$ Agrophytex $+2 \mathrm{~g}$ potassium phosphate)/L and at the high level $\left(4 \mathrm{~cm}^{3}\right.$ Agrophytex $+4 \mathrm{~g}$ potassium phosphate)/L significantly increased lint $\%$ from 38.91 and
$39.58 \%$ in the control treatment to 42.47 and $42.63 \%$; 42.49 and $42.47 \%$ in the first and second seasons, respectively. Also, they significantly increased seed index by 6.19 and $8.48 \% ; 16.55$ and $13.19 \%$, number of open bolls plant ${ }^{-1}$ by 37.58 and $33.47 \% ; 21.53$ and $16.90 \%$ and boll weight by 10.25 and $11.66 \% ; 29.41$ and $39.07 \%$ over the control treatment in 2019 and 2020 seasons, respectively. In addition, foliar feeding with each compound alone either at the low level or at the high level was significantly superior to control with regard to yield of seed cotton fed $^{-1}$ and its contributory characters in both seasons. The significant increase in yield of seed cotton fed $^{-1}$ due to the application of the two combinations used is mainly attributed to NPK accumulation in cotton leaves (Table 3 ) and its distribution to the sink which plays a vital role in seed cotton yield production.

More dry matter accumulation might be the reason of higher crop growth, where leaves are the units of assimilatory system, therefore, increased leaf area index of cotton might be responsible of increased crop growth due to increased accumulation of assimilates. Application of compounds enriched in $\mathrm{P}$ and $\mathrm{K}$ increased photosynthetic activity and produced higher numbers of flowers and bolls (Table 5).

Table 6. Effect of foliar application with Agrophytex and/or potassium phosphate at two levels on yield and its components in 2019 and 2020 seasons

\begin{tabular}{|c|c|c|c|c|c|}
\hline \multirow[t]{2}{*}{ Treatments } & Lint \% & $\begin{array}{l}\text { Seed } \\
\text { index } \\
(\mathrm{g})\end{array}$ & $\begin{array}{c}\text { Open bolls } \\
\text { number } \\
\text { Plant }^{-1}\end{array}$ & $\begin{array}{c}\text { Boll } \\
\text { weight } \\
\text { (g) }\end{array}$ & $\begin{array}{l}\text { Yield of seed } \\
\text { cotton } \\
\left(\text { kentar fed }^{-1}\right)\end{array}$ \\
\hline & \multicolumn{5}{|c|}{2019 season } \\
\hline T-Control. & 38.91 & 10.02 & 17.48 & 2.83 & 8.87 \\
\hline $\mathrm{T}_{2}$-Agrophytex, $2 \mathrm{~cm}^{3} / \mathrm{L}$. & 39.43 & 10.11 & 20.85 & 2.91 & 9.51 \\
\hline $\mathrm{T}_{3}$-Agrophytex, $4 \mathrm{~cm}^{3} / \mathrm{L}$. & 39.83 & 10.19 & 22.68 & 2.96 & 10.08 \\
\hline $\mathrm{T}_{4}$-Potassium phosphate, $2 \mathrm{~g} / \mathrm{L}$. & 41.76 & 10.26 & 18.23 & 3.01 & 10.04 \\
\hline $\mathrm{T}_{5}$-Potassium phosphate, $4 \mathrm{~g} / \mathrm{L}$. & 41.95 & 10.28 & 19.10 & 3.06 & 10.33 \\
\hline $\mathrm{T}_{6^{-}}\left(\mathrm{T}_{2}+\mathrm{T}_{4}\right)$ & 42.47 & 10.64 & 24.05 & 3.12 & 11.04 \\
\hline $\mathrm{T}_{7-}\left(\mathrm{T}_{3}+\mathrm{T}_{5}\right)$ & 42.63 & 10.87 & 23.33 & 3.16 & 10.69 \\
\hline LSD at 0.05 & 0.20 & 0.11 & 0.69 & 0.08 & 0.41 \\
\hline Treatments & \multicolumn{5}{|c|}{2020 season } \\
\hline $\mathrm{T}_{1}$-Control. & 39.58 & 8.64 & 15.56 & 2.38 & 8.81 \\
\hline $\mathrm{T}_{2}$-Agrophytex, $2 \mathrm{~cm}^{3} / \mathrm{L}$. & 40.42 & 9.07 & 16.60 & 2.77 & 9.75 \\
\hline $\mathrm{T}_{3}$-Agrophytex, $4 \mathrm{~cm}^{3} / \mathrm{L}$ & 40.52 & 9.26 & 16.35 & 2.66 & 9.71 \\
\hline $\mathrm{T}_{4}$-Potassium phosphate, $2 \mathrm{~g} / \mathrm{L}$. & 40.10 & 8.85 & 16.90 & 2.51 & 9.67 \\
\hline $\mathrm{T}_{5}$-Potassium phosphate, $4 \mathrm{~g} / \mathrm{L}$. & 42.11 & 9.57 & 17.62 & 2.92 & 9.92 \\
\hline $\mathrm{T}_{6^{-}}\left(\mathrm{T}_{2}+\mathrm{T}_{4}\right)$ & 42.49 & 10.07 & 18.91 & 3.08 & 10.64 \\
\hline $\mathrm{T}_{7}-\left(\mathrm{T}_{3}+\mathrm{T}_{5}\right)$ & 42.47 & 9.78 & 18.19 & 3.31 & 10.30 \\
\hline LSD at 0.05 & 0.53 & 0.13 & 0.40 & 0.10 & 0.42 \\
\hline
\end{tabular}

It was found that cotton plants treated with compounds enriched in $\mathrm{P}$ and $\mathrm{K}$ have larger photosynthetic sinks for carbohydrates and other metabolites that increased the dry matter accumulation. This process increases boll formation. Similarly, P and K applications improved the photosynthetic activity by reducing squares and bolls shedding, which in turn resulted in heavier boll weight, formation of fully mature seed and heavier seeds than untreated plants. Higher K supply increases translocation of sugars, causing an increment in lint and boll weight, which ultimately increases the yield, however $\mathrm{K}$ deficiency enhanced dry matter partitioning in the leaves instead of the reproductive organs, where it inhibits phloem loading and increases carbohydrate accumulation in cotton leaves (Zhao et al., 2001). This may disturb balance of the overall source sink and shorten period of the boll maturation, resulting in reduced boll number, size and weight, lint $\%$ and lint quality (Read et al., 2006). Significant increase in number of sympodial branches reflects more bolls per unit area, which eventually enhance the productivity. Plants of the control treatment significantly produced lower fruiting branches. Kadam et al. (2017) found that the increasing levels of potassium caused significant increase in yield of cotton.

\section{E- Fiber quality:}

Foliar feeding with the two compounds used enriched with phosphorus and potassium significantly affected micronaire reading and fiber strength in 2020 season only (Table 7), in favor of foliar feeding with Agrophytex and 
potassium phosphate at the high level $\left(4 \mathrm{~cm}^{3}\right.$ Agrophytex +4 g potassium phosphate)/L, followed by the low level $\left(2 \mathrm{~cm}^{3}\right.$ Agrophytex $+2 \mathrm{~g}$ potassium phosphate)/L, where these two levels produced the highest micronaire reading (4.40 and 4.37 micronaire units) and the highest fiber strength (11.33 and 11.30 Pressley units), respectively. The increase of the micronaire is mainly due to the higher cellulose deposition in the secondary wall of the fiber (Heitholt, 1997). Also, foliar feeding with each compound alone at the high level produced the highest values compared to foliar feeding with each compound alone at the low level and the control (sprayed with tap water and fertilized with phosphorus and potassium at the recommended rate as soil application). Lowest fiber strength (10.70 Pressley units) documented in control plots. The low level of potassium phosphate produced the lowest micronaire reading (3.70 micronaire units). The tested treatments gave insignificant effect on $2.5 \%$ span length $(\mathrm{mm})$ and length uniformity ratio (\%) in both seasons. K availability in soil and plant tissues (Tables 1 and 3) affected fiber formation through its effect on several complex physiological processes involved in fiber formation (Zahoor et al. 2017 and $\mathrm{Hu}$ et al. 2018). A number of enzymes are significantly influenced by $\mathrm{K}$ nutritional status and affected fiber elongation such as sucrose synthase, pyrophosphatase, cytoplasmic phosphoenolpyruvate oxylase and vacuolar adenosine triphosphatase (Hu et al., 2018). Activities of sucrose phosphatase synthase (SPS) and sucrose synthase (SS) which serve as the main enzymes for cellulose synthesis during the fiber thickening process are highly dependent upon $\mathrm{K}$ application rate and down-regulation of their activities in response to lower $\mathrm{K}$ availability leads to reduced cellulose concentration and poor cotton fiber strength. (Zahoor et al., 2017; Ali et al., 2018 and Hu et al., 2018).

In this regard, Potassium deficiency can severely impact fiber quality by decreasing fiber uniformity, staple length, fiber strength and micronaire (Pettigrew et al., 2005). Sawan et al. (2008) found that fiber properties did not affect by spraying plants with $\mathrm{P}_{2} \mathrm{O}_{5}$ at the three $\mathrm{P}$ concentrations $\left(0.576,1.152\right.$ and $1.728 \mathrm{~kg}$ of $\left.\mathrm{P} \mathrm{ha}^{-1}\right)$. Yang et al. (2016) found that potassium plays a major role in the fiber formation and development. Eryuce et al. (2019) reported that maturity quality percentage improved clearly by K supply. Higher K supply increases translocation of sugars into the developing boll, causing an increment in cellulose build-up in the fiber cell wall (Xiangbin et al., 2012 and $\mathrm{Hu}$ et al., 2015). AbdelGayed et al. (2020) found that fiber traits were not affected by phosphorus application as foliar spraying twice. Ahmad et al. (2020) reported that spray of $150 \mathrm{~kg}$ phosphorus ha-1 significantly increased fiber staple length, length uniformity ratio, fiber strength and micronaire.

Table 7. Effect of foliar application with Agrophytex and/or potassium phosphate at two levels on cotton fiber traits in 2019 and 2020 seasons.

\begin{tabular}{|c|c|c|c|c|}
\hline Treatments & $\begin{array}{c}\text { Fineness } \\
\text { (micronaire } \\
\text { reading) }\end{array}$ & $\begin{array}{c}\text { Fiber } \\
\text { strength } \\
\text { (Pressley units) }\end{array}$ & $\begin{array}{c}2.5 \% \text { span } \\
\text { Length } \\
\text { (mm) }\end{array}$ & $\begin{array}{c}\text { Uniformity } \\
\text { Ratio } \\
(\%)\end{array}$ \\
\hline & \multicolumn{4}{|c|}{2019 season } \\
\hline $\mathrm{T}_{1}$-Control. & 4.6 & 10.6 & 34.6 & 86.6 \\
\hline $\mathrm{T}_{2}$-Agrophytex, $2 \mathrm{~cm}^{3} / \mathrm{L}$. & 4.5 & 10.4 & 33.9 & 85.9 \\
\hline $\mathrm{T}_{3}$-Agrophytex, $4 \mathrm{~cm}^{3} / \mathrm{L}$. & 4.6 & 10.6 & 34.6 & 86.4 \\
\hline $\mathrm{T}_{4}$-Potassium phosphate, $2 \mathrm{~g} / \mathrm{L}$. & 4.4 & 11.0 & 34.0 & 85.8 \\
\hline $\mathrm{T}_{5}$-Potassium phosphate, $4 \mathrm{~g} / \mathrm{L}$. & 4.4 & 10.4 & 34.2 & 86.0 \\
\hline $\mathrm{T}_{6^{-}}\left(\mathrm{T}_{2}+\mathrm{T}_{4}\right)$ & 4.5 & 10.7 & 34.2 & 86.3 \\
\hline$T_{7-}\left(T_{3}+T_{5}\right)$ & 4.6 & 10.8 & 33.9 & 86.0 \\
\hline LSD at 0.05 & NS & NS & NS & NS \\
\hline Treatments & \multicolumn{4}{|c|}{2020 season } \\
\hline $\mathrm{T}_{1}$-Control. & 3.90 & 10.70 & 33.00 & 84.80 \\
\hline $\mathrm{T}_{2}$-Agrophytex, $2 \mathrm{~cm}^{3} / \mathrm{L}$. & 3.87 & 10.80 & 33.40 & 85.20 \\
\hline $\mathrm{T}_{3}$-Agrophytex, $4 \mathrm{~cm}^{3} / \mathrm{L}$. & 4.10 & 11.20 & 33.40 & 85.17 \\
\hline $\mathrm{T}_{4}$-Potassium phosphate, $2 \mathrm{~g} / \mathrm{L}$. & 3.70 & 10.72 & 33.37 & 85.30 \\
\hline $\mathrm{T}_{5}$-Potassium phosphate, $4 \mathrm{~g} / \mathrm{L}$. & 4.03 & 10.97 & 33.40 & 85.37 \\
\hline $\mathrm{T}_{6^{-}}\left(\mathrm{T}_{2}+\mathrm{T}_{4}\right)$ & 4.37 & 11.30 & 33.60 & 85.60 \\
\hline$T_{7}-\left(T_{3}+T_{5}\right)$ & 4.40 & 11.33 & 33.90 & 86.17 \\
\hline LSD at 0.05 & 0.26 & 0.32 & NS & NS \\
\hline
\end{tabular}

\section{CONCLUSION}

It could be concluded that spraying with combination between Agrophytex and potassium phosphate at the low level four times as alternative to soil $\mathrm{P}$ and $\mathrm{K}$ fertilization to reduce cost, overcome $\mathrm{P}$ and $\mathrm{K}$ fixation and obtain high productivity under conditions similar to El-Gemmeiza region.

\section{REFERENCES}

A.O.A.C. (1995): Association of Official Agriculture Chemists. Official Methods of Analysis. $16^{\text {th }} \mathrm{Ed}$. A.O.A.C. Virginia, DC, USA.

A.S.T.M. (2012): American Society for Testing and Materials. Designation, (D 1447-07), (D 1448-97), (D 1445-67).
Abdel-Gayed, S. Sh.; A. M. Abd El-Hafeez and M. A. A. Ibrahim (2020): Effect of Reducing Mineral Nitrogen and Phosphorus Fertilizer by Foliar Spraying of Phosphorus and Bio-Fertilization on Quality and Quantity of Cotton. J. of Soil Sci. and Agric. Eng., Mansoura Univ., 11 (1): 11- 15.

Ahmad, A.; H. Ali; Sh. Hussain; W. Hassan and R. Ahmad (2020): Supplemental application of phosphorus improves yield, quality and net returns of Gossypium hirsutum. Pure Appl. Biol., 9(4): 2577-2588.

Ali, H.; A. Ahmad and S. Hussain (2020): The effect of exogenous phosphorous application on growth, yield, quality and net returns of Upland cotton (Gossipium hirsutum L.). Appl. Ecol. and Environ. Res., 18(1):769-781. 
Ali, S.; A. Hafeez; X. Ma; S. A. Tung; A. Liu; A. N. Shah; M. S. Chattha; Z. Zhang and G. Yang (2018): Potassium relative ratio to nitrogen considerably favors carbon metabolism in late planted cotton at high planting density. Field Crops Res., 223:48-56.

Amberger, A. (1993): Dynamics of nutrients and reactions of fertilizers applied on the environment. Proc. of German/Egyptian/Arab Workshop in Cairo and Ismailia, Egypt, 6-17 June pp.41-59.

Arya, K. C. and S. N. Singh (2001): Productivity of maize as influenced by different levels of phosphorus, zinc and irrigation. Indian J. of Agric. Sci., 71: 57-59.

Aslam, M.; T. Ahmed and L. Yaseen (2020): Influence of soil and foliar application of potassium fertilization on the growth and yield component of cotton crop in ecological zone of Rahim Yar Khan. Int. J. of Res. in Agric. and Forestry, 7 (Issue 3): 8-12.

Bronson, K. and R. Boman (2009): Nutrient Management for Texas high plains cotton production. Agri. Life Res. and Agri. Life Extention.

Chapman, H. D. and F. P. Parker (1981): "Methods of Analysis of Soil, Plants and Water". Univ. California, August, 1981. Second Printing.

Deshpande, R. M. and B. A. Lakhdive (1994): Effect of plant growth substances and phosphorus levels on yield and phosphorus uptake by cotton. PKV Res. J., 18: 118121.

Dev, R.; A. P. Sharma; K. Promila and B. S. Duhan (2007): Effect of balanced fertilization on seed cotton yield and nutrient uptake by cotton (Gossypium hirsutum, L.) under irrigated condition. J. of Cotton Res. and Dev., 21 (1): 72-74.

Dohary, C. G.; I. J. Rochester and G. J. Blair (2004): Response of field grown cotton (Gossypium hirsutum L.) to phosphorus fertilization on alkaline soils in eastern Australia. Australian J. of Soil Res., 42(8): 913-920.

El-Fouly, M. M. and A. A. El-Sayed (1997): Foliar fertilization: An environmentally friendly application of fertilizers. In Dahlia Greidinger. Int. Symposium on" Fertilization and Environ. (pp. 24-27) March, Haifa, Israel, John I(Ed): pp346-357.

El-Shazly, W. M.; R. Kh. M. Khalifa and O.A. Noval (2003): Response of cotton Giza 89 cultivar to foliar spray with boron, potassium and bioregulator SGA-1. Egypt. J. Appl. Sci., 18(4B): 676 - 699.

Eryuce, N.; C.F. Ozkan; D. Anac; F.Ö. Asri; D. Güven; E.L. Demirtas; M. Simsek and N. Ari (2019): Effect of different potassium fertilizers on cotton yield and quality in Turkey. e-ifc No. 57, June 2019.

Fadeel, A. A. (1962): Location and properties of chloroplasts and pigment determination in shoots. Plant Physiol., 15: 130-137.

Fahad, S.; S. Hussain; S. Saud; S. Hassan; M. Tanveer; M. Z. Ihsan; A. N. Shah; A. Ullah; F. Nasrullah; F. Khan; S. Ullah ; H. Alharby ; W. Nasim ; C. Wu and J. Huang (2016): A combined application of biochar and phosphorus alleviates heat-induced adversities on physiological, agronomical and quality attributes of rice. Plant Physiol. and Biochemistry, 103 (2):191198.

Gilbert, N. (2009): The disappearing nutrient. Nature, 461: $716-718$
Hartt, C. E. (1972): Potassium in soil. $9^{\text {th }}$ Colloquim. Intrenat. Potash Inst., Berne.

Hearn, A.B. (1981): Cotton nutrition. Field Crop Abst., 34(1): 11-34.

Heitholt, J. J. (1997): Floral bud removal from specific fruiting positions in cotton: Yield and fiber quality. Crop Sci., 37 (3): 826-832.

Hu, W.; D. Loka; T. R. Fitzsimmons; Z. Zhou and D. M. Oosterhuis (2018): Potassium deficiency limits reproductive success by altering carbohydrate and protein balances in cotton (Gossypium hirsutum L.). Environ. and Exp. Biology, 145: 87-94.

Hu, W.; J. Yang; Y. Meng; Y. Wang; B. Chen; W. Zhao and Z. Zhou (2015): Potassium application affects carbohydrate metabolism in the leaf subtending the cotton (Gossypium hirsutum L.) boll and its relationship with boll biomass. Field Crops Res.,179: 120-131.

Hunt, R. (1978): Plant growth analysis. The institute of biological studies. Edward Arnold. (Pub) Ltd. UK., 96: 8-38.

Hussain, M; A. F. Tariq; A. Nawaz; M. Nawaz; A. Sattar; S. Ul-Allah and Abdul Wakeel (2020): Efficacy of fertilizing method for different potash sources in cotton (Gossypium hirsutum L.) nutrition under arid climatic conditions. PLoS ONE, 15(1): e0228335.

Kadam, Y. B.; V. K. Kharche; V. S. Borkar; R. N. Katkar; N. M. Konde and V. V. Gabhne (2017): "Effect of potassium application on yield. and nutrient uptake by Cotton”, Int. J. of Current Res., 9(01): 45374-45381.

Kadapa, S.N. (1975): Earliness in cotton I.A study of component characters. AICCIP, Agric. Res. St., Dharwar, India, Mysore. J. of Agric. Sci., 9(2): 219229.

Karim, F.; J. Iqbal; M. Shabbir; Sh. Kaleem and M. Q. Waqar (2016): Response of cotton to foliar and soil applied nutrients under Dera Ghazi Khan conditions. J. of Environ. \& Agric. Sci., 7:14-18.

Lynch, J.P. (2011): Root phenes for enhanced soil exploration and phosphorus acquisition: Tools for future crops. Plant Physiol., 156: 1041-1049.

Mai, W.; X. Xue; F. Gu; Y. Rong and C. Tian (2018): Can optimization of phosphorus input lead to high productivity and high phosphorus use efficiency of cotton through maximization of root/mycorrhizal efficiency in phosphorus acquisition? Field Crops Res., 216: 100-108.

Malik, M. N. A.; M. I. Makhdum and F. I. Chaudhry (1992): Influence of phosphorus fertilization on crop growth, seed cotton yield and fibre quality. Pak J. Sci. and Res., 35: 288-290.

Mandal, K. J. and A. C. Sinha (2004): Nutrient management effects on light interception, photosynthesis, growth, dry-matter production and yield of Indian mustard (Brassica juncea L.). J. Agron. and Crop Sci. 190 (2): 119-129.

Mengel, K. and E. Kirkby (1987): Principles of plant nutrition, 4th ed. International Potash Institute. Bern.

Oosterhuis, D. (2001). Physiology and nutrition of high yielding cotton in the USA. Arkansas Univ. Fayetteville, AR 72701, EUA,18-24.

Oosterhuis, D.; K. Hake and C. Burmester (1991): Foliar feeding cotton. Cotton Physiology Today-News Letter of the Cotton Physiol. Education Program. National Cotton Council, 2(8): 1-8. 
Oosterhuis, D. M. and C. W. Bednarz (1997): Physiological changes during the development of potassium deficiency in cotton. pp 347-351. In, T. Ando et. Al. (eds). Plant Nut. for Sustainable Food Prod. and Environ. Kluwer Academic Publishers, Japan.

Oosterhuis, D. M.; D. A. Loka and T. B. Raper (2013): Potassium and stress alleviation: Physiological functions and management of cotton. J. of Plant Nut. and Soil Sci., 176: 331-343.

Oosterhuis, D. M.; S. D. Wullschleger, R. L. Maples and W. N. Miley (1990): Foliar feeding of potassium nitrate in cotton. Better Crops with Plant Food, 74(3): 8-9.

Parfitt, R. L.; W.T. Baisden and A. H. Elliott (2008): Phosphorus inputs and outputs for New Zealand in 2001 at national and regional scales. J. of the Royal Soc. of New Zealand, 38:1, 37-50

Pettigrew, W. T.; W. R. Meredith and L. D. Young (2005): Potassium fertilization effects on cotton yield, yield components and nematode populations. Agron. J., 97: 1245-1251.

Radin, J. W. and M. P. Eidenbock (1984): Hydraulic conductance as a factor limiting leaf expansion of phosphorus-deficient cotton plants. Plant Physiol., 75: 372-377.

Rajasekar, M.; D. U. Nandhini; V. Swaminathan and K. Balakrishnan (2017): A review on role of macro nutrients on production and quality of vegetables. Int. J. of Chemical Studies, 5(3): 304-309.

Read, J. J.; K. R. Reddy and J. N. Jenkins (2006): Yield and fiber quality of Upland cotton as influenced by nitrogen and potassium nutrition. Europ. J. Agron., 24: $282-290$.

Richmond, T.R. and S.R.H. Radwan (1962): Comparative study of seven methods of measuring earliness of crop maturity in cotton. Crop Sci., Vol. 2: 397-400.

Russell, E. W. (1973): Soil Condition and Plant Growth. The English Language Book Society.
Sawan, Z. M.; M. H. Mahmoud and A. H. El-Guibali (2008): Influence of potassium fertilization and foliar application of zinc and phosphorus on growth, yield components, yield and fiber properties of Egyptian cotton (Gossypium barbadense L.). J. of Plant Eco., 1(4): 259-270.

Sharpley, A.; H. Jarvie; D. Flaten and P. Kleinman (2018): Celebrating the 350th Anniversary of Phosphorus Discovery: A Conundrum of Deficiency and Excess. J. Environ. Qual., 47: 774- 777.

Snedecor, W. G. and G. W. Cochran (1980): Statistical Methods. $7^{\text {th }}$ Ed., the Iowa State Univ. Press, Ames, Iowa, USA

Uchida, R. (2000): Essential nutrients for plant growth: Nutrient functions and deficiency symptoms. In: "Plant Nutrient Management in Hawaiis Soils. Approaches for Tropical and Subtropical Agriculture". Chapter 3: 31-55.

Wang, X. L.; H. Q. Yu; N. Liu; B. Yi and M. J. Cao (2012): Physiological characteristics of delaying leaf senescence in maize inbred lines tolerant to potassium deficiency. Acta Agron. Sin., 38: 1672-1679.

Xiangbin, G.; W. Youhua; Z. Zhiguo and D. M. Oosterhuis (2012): Response of cotton fiber quality to the carbohydrates in the leaf subtending the cotton boll. J. of Plant Nut. and Soil Sci., 175(1):152-160.

Yang, J.; W. Hu; W. Zhao; Y. Meng; B. Chen; Y. Wang and Z. Zhou (2016): Soil potassium deficiency reduces cotton fiber strength by accelerating and shortening fiber development. Sci Rep UK, 6:28856.

Young, A. J. (1991): The photoprotective role of carotenoids in higher plants. Physiol. Plant, 83: 702-708.

Zahoor, R.; H. Dong; M. Abid; W. Zhao; Y. Wang and Z. Zhou (2017): Potassium fertilizer improves drought stress alleviation potential in cotton by enhancing photosynthesis and carbohydrate metabolism. Environ. Exp. Bot., 137: 73-83

Zhao, D.; D. M. Oosterhuis and C.W. Bednarz (2001): Influence of potassium deficiency on photosynthesis, chlorophyll content, and chloroplast ultra-structure of cotton plants. Photosynthetica, 39 (1): 103-109.

\footnotetext{
تأثير الرش الورقى بمركبات غنية بالبوتاسيوم والفوسفور كبديل للإضافة الأرضية على نمو وإنتاجية وجودة القطن

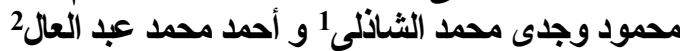

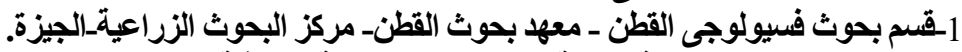

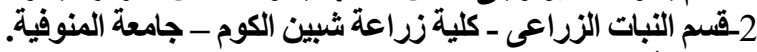

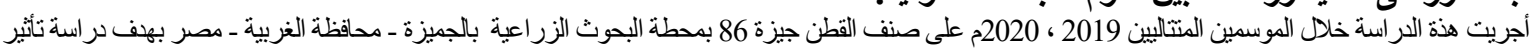

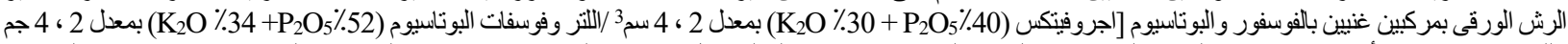

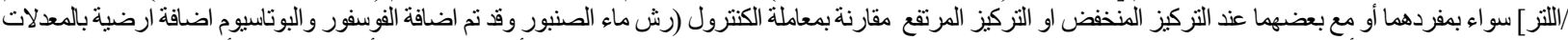

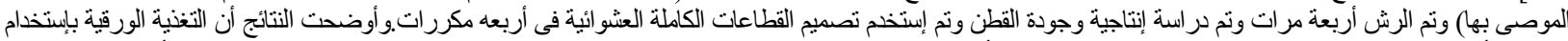

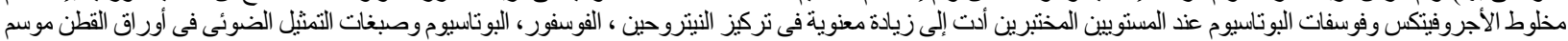

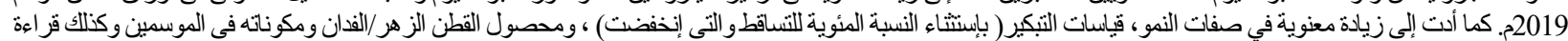

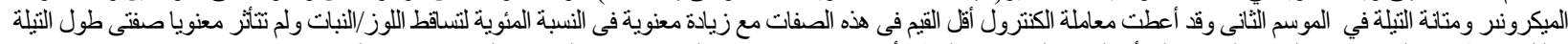

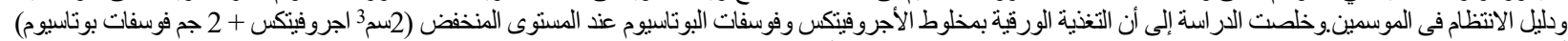

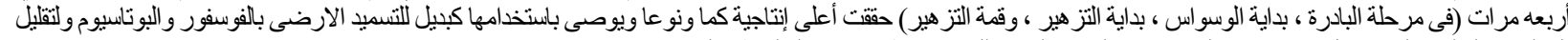

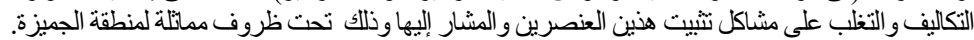

